\title{
PENERAPAN MODEL LEARNING CYCLE UNTUK MENINGKATKAN KEMAMPUAN LITERASI MATEMATIKA
}

\author{
Syarah Aini ${ }^{1}$, Yayan Carlian ${ }^{2}$, dan Dede Rohaniawati ${ }^{3}$ \\ 1,3Jurusan Pendidikan Guru Madrasah Ibtidaiyah, Universitas Sunan Gunung Djati, Indonesia \\ 2Jurusan Pendidikan Agama Islam, Universitas Sunan Gunung Djati, Indonesia \\ E-mail: Arasyarah14@gmail.com
}

\begin{abstract}
Abstrak
Penelitian bertujuan untuk mendapatkan gambaran mengenai kemampuan literasi metematika siswa sebelum dan setelah menggunakan model Learning Cycle 5E. Metode yang digunakan adalah Penelitian Tindakan Kelas (PTK). Subjek penelitian ini siswa kelas III MI Matla'ul Atfal Kota Bandung yang berjumlah 18 orang. Berdasarkan hasil penerapan model Learning Cycle 5E adanya peningkatan aktivitas guru dan siswa. Hasil aktivitas guru siklus 1 tindakan I, $88 \%$, siklus I tindakan II, 94\%, siklus II tindakan I, 100\%, siklus II tindakan II, 100\%. Hasil aktivitas siswa siklus I tindakan I, $60 \%$, siklus I tindakan II, 71\%, siklus II tindakan I, 79\%, siklus II tindakan II, $86 \%$. Kemampuan literasi matematika siswa pra siklus hanya memperoleh nilai rata-rata 47 (sangat kurang), pada siklus I tindakan I memperoleh hasil 64 (kurang), pada siklus I tindakan II meningkat dengan hasil 76 (cukup baik), selanjutnya pada siklus II tindakan I mengalami peningkatan dengan hasil 79 (baik) dan tindakan II memperoleh hasil cukup memuaskan yaitu 81(baik). Maka dapat disimpulkan bahwa menggunakan model Learning Cycle 5E dapat meningkatkan kemampuan literasi matematika siswa.
\end{abstract}

Kata kunci: Kemampuan Literasi Matematika, Literasi Matematika, LC

\section{PENDAHULUAN}

Cigdem Arslan (2012) mengatakan, "A mathematically literate citizen realizes how quickly change is taking place and the consequent need to be open to lifelong learning. Adapting to these changes in a creative, flexible and practical way is a necessary condition for successful citizenship. The skills learned at school will probably not be sufficient to serve the needs of citizens for the majority of their adult life." Jadi, ahli matematika menyadari perubahan terjadi secara cepat dan konsekuensinya sehingga perlu adanya pembelajaran sepanjang hidupnya. Keterampilan yang didapatkan di sekolah belum mampu melayani sebagian besar kehidupannya. Beradaptasi dengan perubahan-perubahan yang terjadi dengan cara kreatif, fleksibel dan praktis merupakan kondisi yang diperlukan untuk kewarganegaraan yang sukses.

Kemampuan mengolah informasi, inovatif, kreatif dalam memecahkan masalah diharapkan dapat dikembangkan melalui mata pelajaran yang diajarkan di sekolah. Matematika adalah salah satu pelajaran wajib yang diharapkan tidak hanya membekali kemampuan siswa untuk perhitungan atau rumus dalam mengerjakan soal saja tetapi juga harus mampu melibatkan kemampuan bernalar dan analitik untuk memecahkan masalah sehari-hari.

OECD (2014) menyatakan "The mathematical literacy as one's ability to formulate, apply and interpret mathematics within various contexts, including the ability to do mathematical reasoning and using concepts, procedures, and facts to describe, explain or estimating phenomena / events".(OECD, 2014). Jadi, literasi matematika merupakan kemampuan seseorang dalam merumuskan, mengaplikasikan, menafsirkan matematika dalam berbagai konteks, termasuk kemampuan untuk penalaran matematis dan menggunakan konsep, prosedur dan fakta untuk menggambarkan, menjelaskan fenomena/peristiwa.

Kemampuan literasi siswa Indonesia masih rendah, ini terlihat dari penelitian yang telah 
dilakukan oleh PISA. Pada hasil penelitian PISA, Indonesia menempati kedudukan 10 negara terrendah dengan skor rata-rata literasi matematika siswa yaitu 375 yang menempati level 1 (terendah) dari enam level kemampuan literasi matematika yang ditetapkan oleh PISA, sedangkan skor rata-rata internasional kemampuan literasi matematika yaitu 500 yang menempati kedudukan level 3. Hasil penelitian PISA ini terlihat adanya perbedaan kecapaian kemampuan literasi matematika siswa Indonesia. (Safarandes, 2017)

Berdasarkan studi pendahuluan di MI Matla'ul Athfal, sebagian siswa belum mampu memahami konsep matematika dan hanya menghafal rumus-rumus saja. Kemampuan literasi matematika belum dimiliki oleh siswa seperti: membaca sebuah soal cerita (data) yang akan diterjemahkan dalam model matematis, mengidentisikasi sebuah permasalahan serta memilih strategi yang harus digunakan saat menyelesaikan sebuah permasalahan, sehingga pengaplikasian dalam kehidupan sehari-hari belum mampu diterapkan. Selain itu, proses pelaksanaan kegiatan belajar jarang menggunakan alat peraga sebagai alat bantu dalam menyampaikan materi dan metode pembelajaran kurang mendukung adanya pembiasaan siswa dalam meningkatkan literasi matematika siswa.

Diyarko (2016), mengatakan faktor-faktor yang menyebabkan rendahnya siswa dalam mengerjakan soal-soal literasi matematika adalah tidak adanya pembiasaan yang dilakukan oleh guru, media dan metode yang digunakaan saat pembelajaran kurang mendukung serta guru lebih banyak memberikan penjelasan materi yang berdampak siswa minim sekali dalam membangun pengetahuannya.

Model pembelajaran yang diasumsikan untuk meningkatkan kemampuan literasi matematika siswa dapat menggunakan model Learning Cycle. Model Pembelajaran Learning Cycle atau siklus belajar adalah model pembelajaran yang berpusat pada siswa (student center) yang merupakan rangkaian tahapan-tahapan kegiatan (fase) yang diorganisasi sedemikian rupa sehingga siswa dapat menguasai kompetensi-kompetensi yang harus dicapai dengan pembelajaran aktif (Fajaroh, 2008). Model pembelajaran Learnig Cycle terdapat tiga tipe yaitu Learnig Cycle 3E, Learning Cycle 5E dan Learnig Cycle 7E. Rahayuningsih (2012), mengatakan dalam pembelajaran dengan Learnig Cycle 5E siswa aktif bertanya, menjawab, mengerjakan soal ke depan dan berdiskusi kelompok untuk memecahkan permasalahan dan menemukan konsep sendiri bersama kelompoknya.

Menurut Anthony W. Lorsbach (2002), langkah-langkah pembelajaran dengan model Learning Cycle 5E adalah:

Tahap Engagement

Tahap ini guru mengondisikan siswa untuk belajar, membangkitkan minat siswa pada pelajaran matematika, dan melakukan tanya jawab dalam mengeksplorasi pengetahuan awal siswa.

Tahap Exploration

Tahap ini siswa bekerja sama dalam kelompok-kelompok kecil untuk mengerjakan LKS tanpa pengajaran langsung dari guru. Siswa mempelajari konsep sendiri dari berbagai sumber yang dimiliki dan mendiskusikan dengan teman kelompoknya. Dalam hal ini guru berperan sebagai fasilitator.

Tahap Explanation

Tahap ini merupakan tahap diskusi klasikal. Pada tahap ini siswa menjelaskan konsep hasil temuan kelompoknya dengan bahasa mereka sendiri, menunjukkan bukti dan klarifikasi dari penjelasan mereka, serta membandingkan argumen yang mereka miliki dengan argumen dari siswa lain.

Tahap Elaboration.

Tahap ini siswa menerapkan konsep yang mereka dapatkan untuk menyelesaikan soal-soal pemecahan masalah.

Tahap Evaluation

Tahap ini evaluasi yang dapat dilakukan dengan pemberian tes) atau open-ended question di akhir pembelajaran untuk mengetahui sejauh mana tingkat pemahaman siswa terhadap konsep yang dipelajari. 


\section{METODE/EKSPERIMEN}

Metode penelitian yang digunakan dalam penelitian ini adalah Penelitian Tindakan Kelas (Classroom Action Research). Penelitian Tindakan Kelas merupakan satu bentuk penelitian yang bersifat reflektif dengan melakkan tindakan-tindakan tertentu untuk memperbaiki atau meningkatkan praktik-praktik kegiatan pembelajaran di kelas secara profesional. (Suyanto, 1997:4). Pelaksanaan PTK berupa proses pengkajian berbaur (siklus). Penelitian ini merupakan salah satu upaya guru atau praktisi dalam bentuk berbagai kegiatan yang dilakukan untuk memperbaiki dan meningkatkan mutu pembelajaran di kelas, (Salahudin, 2015:24). Penelitian tindakan kelas ini akan dilaksanakan selama dua siklus dengan masing-masing siklus dengan dua kali tindakan atau pertemuan. Setiap siklus terdiri dari perencanaan, pelaksanaan, observasi dan refleksi.

Jenis data yang digunakan adalah data kualitatif dan kuantitatif. Data kualitatif adalah data yang disajikan dalam bentuk kata verbal bukan dalam bentuk angka.(Muhadjir. 1996:2). Sedangkan data kuantitatif adalah jenis data yang dapat diukur atau dihitung secara langsung, yang berupa informasi atau penjelasan yang dinyatakan dengan bilangan atau berbentuk angka. (Sugiyono. 2010:15).

Sumber data dalam penelitian ini adalah sumber data primer dan sumber data sekunder. Data Primer, yaitu sumber data pokok yang dibutuhkan saat penelitian (Slamet \& Suwanto, 2007:38). Sumber data ini diperoleh dari keadaan langsung di dalam kelas dan hasil tes literasi siswa.Sedangkan Data sekunder, yaitu sumber data tambahan untuk menunjang penelitian (Slamet \& Suwanto, 2007:38). Sumber data ini berupa dokumen, yaitu Silabus, RPP dan dokumentasi.

Teknik pengumpulan data yang digunakan menggunakan observasi dan tes. Observasi dilakukan untuk mengamati dan mengetahui konerja guru dan aktivitas siswa dalam pembelajaran dengan menggunakan model Learning Cycle 5E. Dalam penelitian ini, tes digunakan yaitu tes objektif berupa uraian yang terdiri dari 2 soal untuk memperoleh informasi tentang sejauh mana peningkatan hasil belajar siswa dengan menggunakan model Learning Cycle $5 E$.

Teknik analisis data yang digunakan dalam penelitian ini untuk menghitung hasil lembar observasi setiap siklus. Kemudian dirata-ratakan dan dipresentasikan ke dalam grafik sederhana.

Persentasi dihitung dengan persamaan:

Persentase aktivitas guru $=\frac{\text { skor } \text { yang diperoleh guru }}{\text { skor maksimal }} \times 100$

Persentase aktivitas siswa $=\frac{\text { skor yang diperoleh siswa }}{\text { skor maksimal }} \times 100$

\section{Tabel 1 Interpretasi Keterlaksanaan}

\begin{tabular}{|c|c|c|c|}
\hline $\begin{array}{l}\text { Tingkat } \\
\text { Penguasaan }\end{array}$ & $\begin{array}{l}\text { Nilai } \\
\text { Huruf }\end{array}$ & obot $B$ & Predikat \\
\hline $86-100 \%$ & $A$ & 4 & baik \\
\hline $76-85 \%$ & $B$ & 3 & Baik \\
\hline $60-75 \%$ & $\mathrm{C}$ & 2 & Cukup \\
\hline $55-59 \%$ & $\mathrm{D}$ & 1 & Kurang \\
\hline$\leq 54 \%$ & $\overline{T L}$ & 0 & $\begin{array}{l}\text { Kurang } \\
\text { sekali }\end{array}$ \\
\hline
\end{tabular}

Sumber: Purwanto, 2008

Teknik pengolahan data dari tes beruopa ketuntasan individual, ketuntasan klasikal.

Untuk mengetahui ketercapaian individu menggunakan rumus sebagai berikut: 
Ketuntasan Individual $=\frac{\text { jumlah jawaban yang benar }}{\text { jumlah skor maksimal }} \times 100$

Mengubah Jumlah Skor yang diperoleh menjadi nilai rata-rata keseluruhan dengan rumus:

Keterangan:

$$
\text { Rata-rata }(\mathrm{x})=\frac{\Sigma \mathrm{X}}{\Sigma N} \times 100
$$

$$
\begin{array}{ll}
\mathrm{x} & =\text { Nilai Rata-rata } \\
\Sigma \mathrm{X} & =\text { Jumlah nilai siswa keseluruhan } \\
\Sigma N & =\text { Jumlah siswa }
\end{array}
$$

Tabel 2 Kriteria Penilaian Ketuntasan Individual

Sumber Hayati 2013

\begin{tabular}{|l|l|c|}
\hline 0 & Persentase (\%) & Kategori \\
\hline & $86-100$ & Sangat \\
\hline & $76-85$ & Baik \\
\hline & $60-75$ & Cukup \\
\hline & $55-59$ & Kurang \\
\hline & $\leq 54$ & $\begin{array}{c}\text { Sangat } \\
\text { Kurang }\end{array}$ \\
\hline
\end{tabular}

Untuk mengetahui skor yang diperoleh menggunakan rumus:

Ketercapaian klasikal $=\frac{\text { jumlah siswa yang tuntas }}{\text { jumlah seluruh siswa }} \times 100 \%$

Tabel 3 Kriteria Penilaian Ketuntasan Klasikal

\begin{tabular}{|l|l|c|}
\hline 0 & Persentase (\%) & Kategori \\
\hline & $>70 \%$ & Rendah \\
\hline & $70-79 \%$ & Cukup \\
\hline & $80-89 \%$ & Tinggi \\
\hline & $90-100 \%$ & Sangat \\
& & Tinggi \\
\hline
\end{tabular}

Sumber Hayati 2013

\section{HASIL DAN PEMBAHASAN}

A. Deskripsi Hasil Aktivitas Guru

Aktivitas guru pada penelitian ini, dapat dikatakan setiap siklus dan setiap tindakannya mengalami peningkatan, hal ini dibuktikan melalui lembar observasi aktivitas guru yang telah dinilai oleh observer. Untuk melihat perbandingan dari setiap siklus nya dapat dilihat pada grafik berikut ini: 


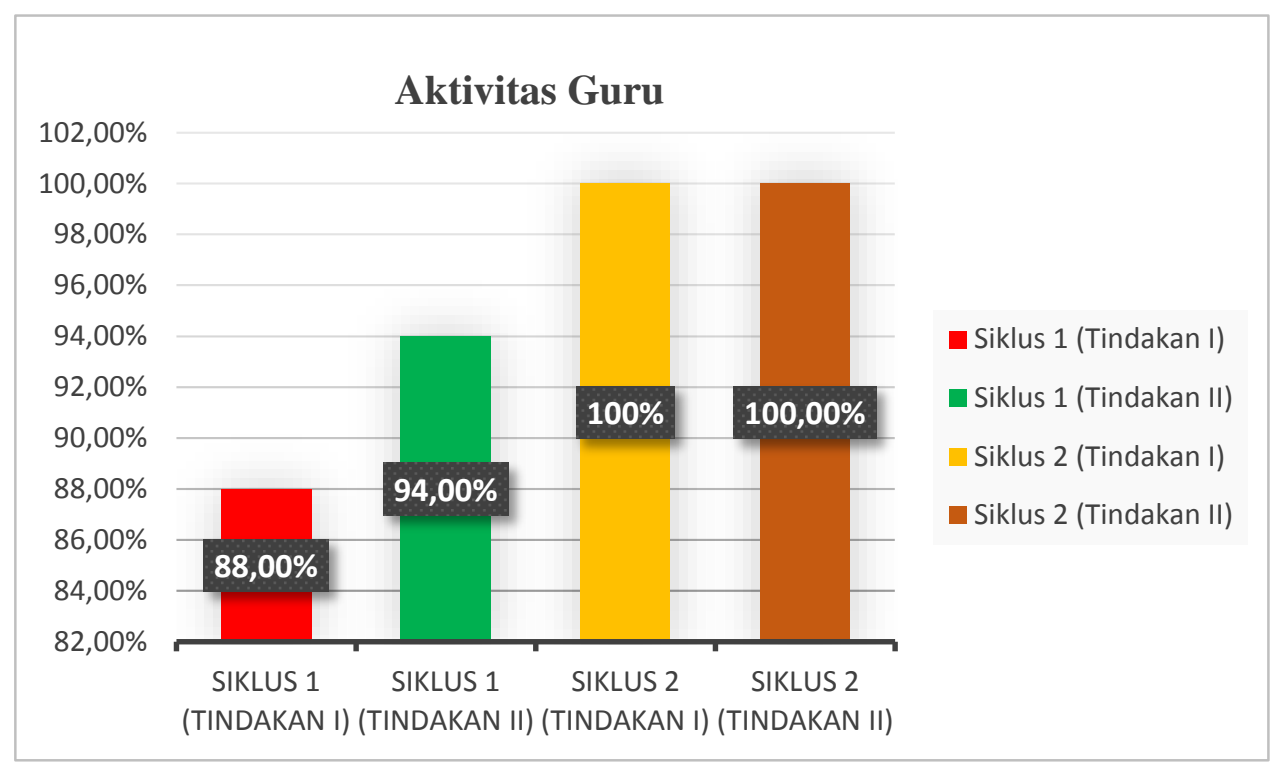

Gambar 1 Grafik Persentase Aktivitas Guru

Berdasarkan grafik di atas, maka dapat disimpulkan bahwa aktivitas guru dalam proses pembelajaran menggunakan model Learning Cycle $5 E$ pada setiap tindakan di setiap siklusnya mengalami peningkatan. Dilihat dari siklus I tindakan I memperoleh sebesar nilai $88 \%$, selanjutnya pada siklus I tindakan II aktivitas guru dalam kegiatan pembelajaran mengalami peningkatan sehingga memperoleh nilai sebanyak $94 \%$. Lalu pada siklus II baik tindakan I maupun tindakan II mengalami peningkatan dibandingkan dengan siklus I tindakan II yaitu memperoleh nilai sebanyak $100 \%$.

B. Deskripsi Hasil Aktivitas Siswa

Aktivitas Siswa pada penelitian ini, bahwa setiap siklus dan tindakannya mengalami peningkatan, hal ini dibuktikan dengan lembar observasi aktivitas siswa yang dinilai oleh guru saat pembelajaran berlangsung. Untuk melihat perbandingan dari setiap siklus nya dapat dilihat pada grafik berikut ini:

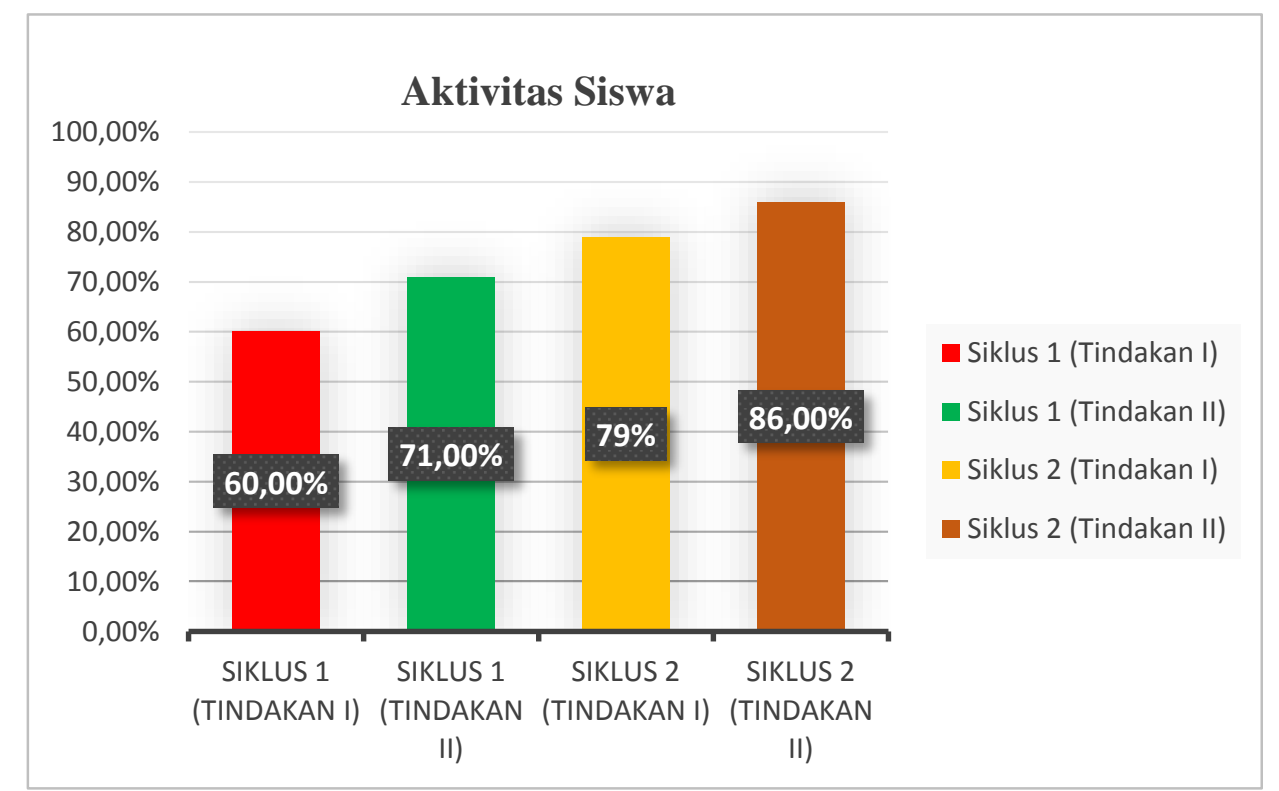

Gambar 2 Grafik Persentase Aktivitas Siswa

Berdasarkan grafik diatas, maka dapat disimpulkan bahwa aktivitas siswa dalam proses pembelajaran untuk meningkatkan kemampuan literasi matematika siswa mengalami peningkatan setiap tindakan pada tiap siklusnya. Pada siklus I tindakan I aktivitas siswa memperoleh nilai sebanyak $60 \%$, lalu mengalami peningkatan pada siklus I tindakan II memperoleh nilai sebanyak 71 
$\%$, selanjutnya pada siklus II tindakan I juga mengalami peningkatan dari tindakan sebelumnya dengan memperleh nilai sebanyak $79 \%$ dan terakhir pada siklus II tindakan II pun mengalami peningkatan yaitu memperoleh nilai sebanyak $86 \%$ yang mendapatkan kategori (sangat baik).

C. Deskripsi Hasil Kemampuan Literasi Matematika

Hasil kemampuan literasi matematika siswa melalui mengerjakan soal-soal literasi matematika level 1 pada siswa kelas III MI Matla'ul Atfal mengalami peningkatan setiap siklus dan tindakannya dengan menggunakan model Learning Cycle 5E. hal ini didapatkan dengan dilakukan test tiap tindakannya sebanyak 2 soal. Adapun jika dilihat hasil kemampuan literasi matematika siswa pasa setiap tindakannya dapat dilihat dari grafik dibawah ini.

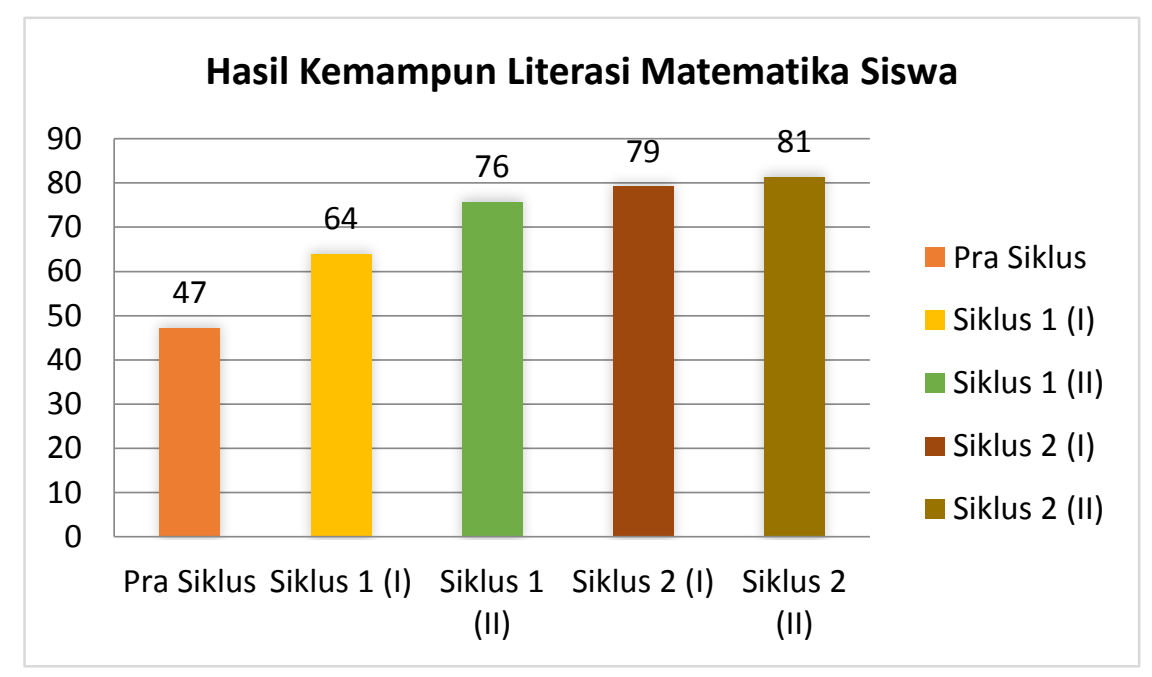

Gambar 3 Grafik Kemampuan Literasi Matematika

Berdasarkan dari gambar 4.20, bahwa kemampuan literasi matematika siswa kelas III pada setiap tindakannya mengalami peningkatan setelah menggunakan model pembelajaran learning cycle $5 E$. Pada pras iklus memperoleh nilai rata-rata 47 dengan kategori sangat kurang. Selanjutnya pada siklus I tindakan I memperoleh hasil 64 dengan kategori kurang, selanjutnya pada siklus I tindakan II memeperoleh hasil 76 dengan kategori baik. Kemudian pada siklus II tindakan I memperoleh hasil 79 dengan kategori baik, pada tindakan II di siklus II memperoleh 81 dengan kategori baik.

\section{PENUTUP}

Berdasarkan hasil penelitian, maka dapat disimpulkan bahwa penerapan model learning Cycle $5 E$ pada kemapuan literasi matematika siswa mengalami peningkatan. Aktivitas guru dan aktivitas siswa pada setiap tindakan dan setiap siklus mengalami peningkatan yang signifikan. Pada siklus I tindakan I aktivitas guru sebesar $81,25 \%$ sedangkan aktivitas siswa sebesar $68 \%$, pada siklus I tindakan II aktivitas guru meningkat menjadi $87,50 \%$ dan aktivitas siswa meningkat menjadi $73 \%$. Kemudian aktivitas guru pada siklus II tindakan I memperoleh persentase sebesar $93,75 \%$ dan aktivitas siswa memperoleh persentase sebesar $84 \%$, pada siklus II tindakan II aktivitas guru meningkat menjadi $100 \%$ dan aktivitas siswa juga meningkat menjadi $92 \%$. Hal ini membuktikan bahwa adanya suatu peningkatan aktivitas guru dan siswa pada setiap siklusnya dalam mata pelajaran matematika dengan menggunakan metode jarimatatika. Adapun hasil belajar pada siklus I tindakan I hasil belajar siswa kelas II ini memperoleh nilai rata-rata 62,36 , kemudian nilai sedikit mengalami peningkatan pada siklus I tindakan II memperoleh nilai rata-rata 65,75 dan pada siklus II tindakan I memperoleh nilai rata-rata 73,48 dan pada siklus II tindakan II memperoleh nilai 78,18. Adapun presentase hasil belajar siswa pada siklus I tindakan I yaitu $72,7 \%$, pada siklus I tindakan II memperoleh $75,7 \%$, kemudian pada siklus II tindakan I yaitu $81,8 \%$ dan pada tindakan II mengalami peningkatan persentase yang sangat pesat yaitu $100 \%$. Dalam mata pelajaran matematika untuk tingkat $\mathrm{Ml}$ dan sederajat biasanya susah untuk memahami materi, tetapi untuk sekarang sudah saatnya menggunakan inovasi-inovasi baru seperti munculnya pendekatan, strategi, ataupun model 
pembelajaran yang kontekstual atau yang nyata sesuai dengan kehidupan sehari-hari siswa yang ada disekelilingnya yang akan menjadikan siswa untuk belajar secara kontekstual atau real. Maka, dengan adanya suatu inovasi baru dalam pembelajaran, siswa akan lebih memahami dan lebih cepat menangkap materi yang disampaikan oleh guru, sehingga pembelajaranpun berjalan secara efektif dan sesuai dengan apa yang diharapkan.

\section{UCAPAN TERIMAKASIH}

Penulis mengucapkan terimakasih yang sebesar-besarnya untuk kedua pembimbing yaitu $\mathrm{H}$. Yayan Carlian, M.Pd. dan Dede Rohaniawati, M.Pd.atas bimbingan yang telah diberikan kepada penulis serta walimurid dan siswa yang telah berkenan membantu dalam penelitian ini.

\section{DAFTAR PUSTAKA}

Andes Safarandes, dkk. (2017). Analisis Kemampuan Literasi Matematika Siswa Kelas X Berdasarkan Kemampuan Matematika.Scholaria, vol 7 no 2: 135-142

Aisyah, Ade (2013). Landasan Pendidikan. Bandung: Alfabeta.

Anthony W. Lorsbach. (2002). The Learning Cycle as A tool for Planning Science Instruction. Online (http://www.coe.ilstu.edu/scienceed/lorsbach/257lrcy.html, diakses pada 20 Maret 2018)

Cigdem Arslan. (2012). A study on mathematical literacy self-efficacy beliefs of prospective teacher. Social and behavioral Sciences. 46

Fajaroh F dan I.W. Dasna. (2008). Model-Model Pembelajaran Inovatif:Pembelajaran dengan Model Siklus Belajar (Learning Cycle). Malang: UM Press.

Hayati, Tuti (2013). Evaluasi Pembelajaran. Bandung: CV. Insan Mandiri.

Heruman, (2013). Model Pembelajaran Matematika di Sekolah Dasar. Bandung: PT Remaja.

Nurul Haq, Dadan (2012). Pendidikan Akidah Akhlak. Bandung: Fajar Media

OECD. (2014). "PISA 2012" Results: What Students Know and Can Do". OECD Publications, vol.1. (Februari 2014:5-61).

Purwanto, Ngalim (2012). Prinsip-prinsip dan Teknik Evaluasi Pengajaran: PT Remaja Rosdakarya

Rizema Putera, Sitiatavia (2012). Berbagai Alat Bantu Untuk Memudahkan Belajar Matematika. Yogyakarta: Diva Press.

Ruseffendi (1991). Pengantar Kepada Membantu Guru Mengembangkan Kompetensinya dalam pengajaran Matematika untuk Meningkatkan CBSA. Bandung; Tarsito Bandung.

Sunar Prasetyono, Dwi (2008). Pintar Jarimatika. Yogyakarta: Diva Press.

Suryadi, Didi (2012). Membangun Budaya Baru dalam Berfikir Matematika. Bandung: Rizqi Press. 